\title{
Walls, Alleys, and Dead Ends: Street Walking as Design for Livability and Community
}

\author{
Calenthia Dowdy
}

\begin{abstract}
Modernist design creates urban spaces that exclude people and neighborhood cultures. Sustainable urban planning is built with human scale in mind. It is messy, but facilitates community. This paper traces the move to sustainable urban planning and suggests that it parallels the Christian understanding of a God who "sits high, but looks low."
\end{abstract}

\section{Cityscapes}

I'm a city girl. ${ }^{1}$ Born and raised in Philadelphia and convinced as a child of the virtues of city life with its diverse masses of people, colorful hues, arrays of cultures and ethnicities. Cities have always excited me. The smells of ethnic foods grabbing my nose as I walked by mom and pop restaurants and greasy grills; a food lover and perpetual people watcher from birth. It seems obvious to me now that I would grow to become a cultural anthropologist since that is essentially what we do. We watch people. And it's no mistake that I would become an anthropologist with a view toward cites. The hodgepodge and seeming disorder of cities was energizing. The pulse, rhythm, even the cacophony, or better yet, the improvised nature, like jazz, not knowing where it's going, but sometimes it sounds good getting there. Cities appeared to be out of order, no plan, or so I thought, just buildings and people strewn about, and maybe, when you really looked close, a glimpse of God here or there.

When I was in college I got a summer job that put me in the middle of New York City every week picking up kids from the various barrios around NYC and helping to transport them to overnight camp somewhere in New Jersey. I remember walking up and down $14^{\text {th }}$ street watching New Yorkers, windowshopping and listening in on people's conversations. Three-card molly was a card game I learned in front of a corner bodega and played while riding busses in NYC. It was a tricky card game that the street hustlers always won, but if by chance they let you win, you were strongly encouraged to play again for an increased pot of money. The hustlers needed to win their money back, plus some of yours.
Way back in high school when it was cool to sit in the back of the bus, some kid with a huge hand-held radio we called a boom-box, would blast rap music. I think it was there in the back of the bus where I learned all the words to Sugar Hill Gang's Rapper's Delight, and Grand Master Flash and the Furious Five's The Message.

Don't...push...me...cuz...I'm...close...to...the...

edge. I'm...try...ing...not...to...lose...my...head. It's like a jungle sometimes, it makes me wonder how I keep from going under!

One summer while in college I met and fell in love with a guy from Brooklyn. We met while working at summer camp. He lived in a housing project in BedfordStuyvesant, a neighborhood in north-central Brooklyn, and I took great delight in visiting him and his family there. On my visits, he and I would go out and ride the trains together, marveling at all the bubble art graffiti on trains, inside trains, on sides of buildings, on subway walls, wondering how the graffiti artists were able to tag some of the locations they tagged high up on billboards, or way atop buildings. How'd they get up there? And once up there how'd they keep their balance to draw or write so well? The mysteries of graffiti artists.

One New Years' Eve a group of my Brooklyn friends decided to go to Times Square to watch the ball drop. We ventured out late. When we arrived at Times Square and tried to exit the subway train, we managed to exit the doors but couldn't get out of the underground. It was so packed the crowds of people flowed down the subway steps and into the underground. We were trapped there in the subway

\footnotetext{
${ }^{1}$ This article is derived from a lecture delivered as part of the Windows on the World series at Eastern University. It uses an intentionally informal and rhetorical style.
} 
station, never made it out in time, so we celebrated the new year right there, underground.

My first job out of college was working in a community center doing youth outreach and driving the van. Besides doing pick-ups and drop-offs in the van, I also walked the streets and hung out with the kids. City kids knew where to find all the hidden gems in their neighborhood. The shortcuts, back alleys, dead-ends, gardens, speakeasies, where the homeless slept, odd and peculiar people and animals. I began to realize that kids see parts of the city adults never see because adults are usually driving or riding, not walking. We walked the maze of the then housing project where we were, exploring and discovering other sides of street life.

A couple of years later I landed in seminary and one of my professors, Dr. Roger Greenway (may he rest in peace) would say in urban missiology class, "If you really want to know the landscape of a neighborhood, walk through it with the kids because they know where everything is located." Schools, parks, daycares, libraries, police stations, community centers, playgrounds, pools...everything.

While in seminary I'd get in my car and drive through the streets of Philly, and dream of what ministry in certain neighborhoods would be like after seminary. I'd drive and watch. The old ladies pushing or pulling groceries in a shopping cart, the girls playing jump rope, the boys playing ball. The men standing on corners smoking and talking loud. Poverty. Yes, there was poverty, but there was also community and togetherness. From my vantage point, the inner city was already a place of hope and held great promise.

\section{Urban Design}

It was the people who made cities amazing and captivating, but there were problematic issues at the core of cities as well. It was the 1980s and soon I began to have questions about resources, economics, space, architectural design, and why so many churches were leaving cities. Businesses had been leaving, and people who could flee did so. Why did cities look the way they did and what plan was in place for them? Who was thinking about the development and re-development of our nation's cities since we were well-into the years of urban flight and greater racial and economic divides.

It began as early as the $1940 \mathrm{~s}$, but even into the 1970s as more people of color entered cities more whites departed and took their businesses and houses of faith with them. A recent New York Times piece (Boustan 2017) reads:

White movement to the suburbs coincided with a period of substantial black migration out of the rural South: From 1940 to 1970 , four million blacks settled in industrial cities in the North and West. As they moved in, the fraction of white metropolitan households living in the typical Northern or Western central city fell from two-thirds to onethird.

Ta-Nehisi Coates refers to the white exodus as a "triumph of racist social engineering," and he is not wrong. Many white households moved to suburban towns precisely because black households were effectively excluded from them by real estate agents and mortgage brokers. But that's not the whole story. Even in cities like Minneapolis-St. Paul that had few black migrants, the suburbs were a magnet for newly prosperous families after World War II seeking larger houses and more open space.

And so, I found myself caught in the same debate: Did whites leave cities for racial reasons or for economic ones?

Some additional data can help. I compared the patterns of black migration into cities and white departures for the suburbs in 70 Northern and Western metropolitan areas from 1940 to 1970 . I found that for every black arrival, two whites left the central city. This figure puts a precise value on what contemporaries already suspected: When black people moved in, white people moved out.

If cities looked messy and out of order before, they were looking even more so in the later 1980s and 90s. More depleted of resources, with dilapidated, unoccupied buildings and increasing poverty filling urban landscapes. Most of the white people in my city had departed for the suburbs, taking everything out of it, and leaving black and brown people as the inheritors of a wasteland. This was happening in most major cities across the U.S. (Sugrue 1996, Wilson 1996, Anderson 2000).

Simultaneously, the earliest seeds of gentrification were beginning to take hold in American cities. Many of the people who had fled to the suburbs were beginning to realize the benefits of city life. Walkability, older homes with charm and character, community, retail in close proximity, and potential for a host of coffee shops, bookstores, crafts, bars, and doggy parks. Developers and urban planners would begin buying up property in cities for cheap prices, pushing out the poor people who had been left behind, pushing up property taxes, and making it nearly impossible for poor people to remain in their homes. Then gentrification sped up, and today's reality is that many re-developed city spaces are white and upper-middle class. There remain black, Latino, and Asian neighborhoods since studies show most cities are still segregated by neighborhood. However, as Elijah Anderson (2011 xiv-xv) writes, there are also urban spaces that diverse people groups share: 
This ethos of getting along, as well as the tremendous growth in immigration, has given rise to the emergence of what I call cosmopolitan canopies-settings that offer a respite from the lingering tensions of urban life and an opportunity for diverse peoples to come together. Canopies are in essence pluralistic spaces where people engage one another in a spirit of civility, or even comity and goodwill. Through personal observation, they may come casually to appreciate one another's difference and empathize with the other in a spirit of shared humanity. Under the canopy this sense of familiarity often breeds comfort and encourages all to be on their best behavior, promoting peaceful relations.

Some years ago, I moved to an international city, Rio de Janeiro, Brazil for a year to collect data for my doctoral program in anthropology. An ex-pat friend from England was returning from a work assignment in Brasilia, the capital of Brazil. She arrived in Rio and sighed a sigh of relief telling me she didn't like Brasilia. "It was pretty," she said, "a perfectly orchestrated city with lots of straight lines, open spaces, and wellmanicured green spaces, but not very functional."

As Brazil's capital city, Brasilia's design was inspired by the Garden City Movement of the early 1900s. A city planner by the name of Sir Ebenezar Howard started these Garden Cities, planned self-contained communities surrounded by greenbelts. They had proportioned residences, businesses and civic locations. Garden Cities looked sharp and clean with their tree-lined streets, perfect angles and sufficient green spaces. They were very rational and modern in design.

Figure 1:

Ebe Ebenezar Howard's Garden City Concept, 1902

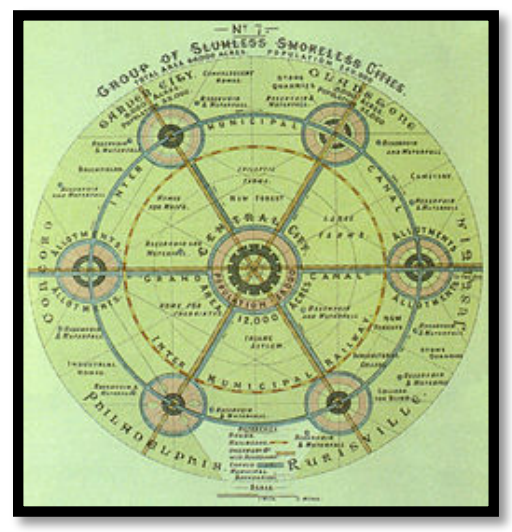

Brasilia was founded in 1957 by city planner, Lucio Costa, and architect, Oscar Niemeyer. It was created to be the new capital of Brazil, located in the interior of the country, unlike the former coastal capital cities of
Salvador and Rio de Janeiro. Brasilia would be the great Modernist city, focusing on minimalism, order, and rationality. It would also be a symbolic city bringing progress to Brazil's interior and by expansion, the entire country. The urban design would include ample space, large monuments, cathedral-like churches and green spaces.

The designers thought the modernist design of the city would be eye-catching and would invoke feelings and images of progress. Perhaps a radically different design would help with radically different social practices. If the city looked different, it would help the people act and envision their lives in different ways. The rational, clean and ordered design would develop rational, clean and ordered citizens. This was the vision.

Figure 2:

Brasilia, the Modernist City

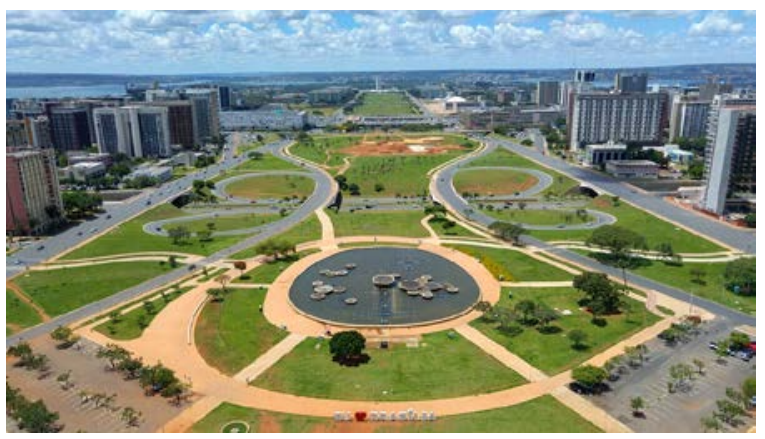

Danish architect and urban design consultant, Jan Gehl (2010) said of Brasilia, "This city was built upon all the great ideas of modernism, and it looks fantastic from an airplane; but if you are down at eye level on your feet walking from place to place, Brasilia is a disaster.”

Gehl went on to say that in this visually pleasing rational design, nobody ever thought about what it would be like to be out in Brasilia living there, walking there, being on the ground. And so, it is a disaster. The architects never imagined the ground level view, they only viewed the city from above. Gehl calls this "bird s*! t" architecture (we'll call it bird poop), in which the architects design by standing above the miniature model of the city and drop buildings here and there without actually knowing the effects on a human scale of where they're placing the buildings .

Cities are about people, cities are about culture, not about buildings. Always consider people and culture first when designing a city. According to Gehl, livable cities include trees, public art, street life and vigor, footpaths, cafes, small civic spaces. Cities must be walkable and people oriented. They must be livable and sustainable spaces. The designer must walk the city in order to know the human scale and create it well. By contrast, Brasilia's human scale was completely 
unrealistic, everything was too big, and there was no concern for human livability.

Gehl challenged urban planners to consider context, not just the grand ideas in their own heads. Go down there, walk the streets, run into alleys, dead-ends and walls. See how it feels to you to walk in the neighborhoods and cities you are crafting. Get intimate with your creation. Walk where people walk, live where the people live. Throw order and rationality out the window. Modernism is too neat for real life. When I think back on my time in Philly walking with the kids, they knew their community best because they walked, they ran, and they played in the streets. They knew their community intimately.

Jane Jacobs was a journalist who lived in NYC during the early to middle twentieth century. She fought the urban planner Robert Moses who was known for breaking up communities for the sake of slum clearance and building highways through neighborhoods for the convenience of suburban dwellers. Roberts operated from above, looking down at models and making his plans. He didn't seem to think about the human element. Jacobs lived in Greenwich village with the people, and was a key resister in the successful cancellation of some of Robert Moses' plans. She argued that Moses tore up families and communities because he didn't know them and didn't understand them. He didn't live there and therefore didn't care. Jacobs lived in the community. She knew about walkability and culture. She knew the devastation that would occur if Moses broke up communities to build highways. In her book, The Death and Life of Great American Cities, Jacobs argued that urban renewal did not respect the needs of real city-dwellers.

Gehl and Jacobs understood urban planning from below. They understood walking with the people. They understood that planning had to include an intimate experience to be successful. One cannot just make plans from above, without going down below to live them out, to see if theory works on the ground. Cities must have intimate human scale walkability.

\section{The Old Church Folk}

When I was kid in church one of the things I used hear the old folks say during testimony time went something like "praise the Lord for a God who sits high and looks low." It was a quizzical statement, one that took me years to understand. A version of the passage can be found in Psalm 113:3-9 (NIV):

${ }^{3}$ From the rising of the sun to the place where it sets, the name of the Lord is to be praised.

${ }^{4}$ The Lord is exalted over all the nations, his glory above the heavens.

${ }^{5}$ Who is like the Lord our God, the One who sits enthroned on high,

${ }^{6}$ who stoops down to look on the heavens and the earth?

${ }^{7}$ He raises the poor from the dust and lifts the needy from the ash heap;

${ }^{8}$ he seats them with princes, with the princes of his people.

${ }^{9}$ He settles the childless woman in her home as a happy mother of children.

Praise the Lord.

Verses 5, 6 and 7 are key to what the old folks knew. "Who is like the Lord our God, the One who sits enthroned on high, who stoops down to look on the heavens and the earth, raising the poor from the dust and lifting the needy from the ash heap...settling the childless woman in her home as a happy mother of children.”

In those verses, we get the image of our God sitting high and majestic enthroned above the earth, but also stooping low to know us intimately. God walks with us on our streets, through alleys, hitting up against those dead-ends with us. The old folks knew that God was ever present. They knew that God had Walkability. God sits high and looks low. God sees and experiences the real lives of God's creation. God is not a grand architect who poops from the skies distant from our reality. God is down in the human grittiness with us. God walks with us and talks with us and tells us we are his own.

This is the essence of incarnation. God here with us...not from a distance...but with us. My love for walking the city streets helped me understand the Incarnation.

\section{Conclusion}

A livable sustainable city is built with human scale in mind. It may not be very pretty from above, it may lack minimalism or order, straight lines and rational spaces, but it is filled with people who also don't have straight, organized, and rational lives. Humans are messy.

Children. Whenever a toddler person is in my midst, I try to remember to get down to their eye level to see what they see. Get on the ground, play, roll and laugh. Experience their reality, their human scale down on the floor. You'd be surprised by what you see down there.

When we make our plans from up here, for the others down there or over there, let's remember to go there and experience what they experience. If you don't get to know the people you're planning for, it's like dropping bird-poop all over them. Sit high if you must, but don't forget to look low. "Who is like the Lord our God, the One who sits enthroned on 
high, who stoops down to look on the heavens and the earth?"

\section{Bibliography}

Anderson, Elijah. 2000. Code of the Street: Decency, Violence, and the Moral Life of the Inner City. New York: W.W. Norton \& Co.

- 2011. The Cosmopolitan Canopy: Race and Civility in Everyday Life. New York: W.W. Norton \& Co.

Boustan, Leah. May 15, 2017. "The Culprits Behind White Flight.”

https://www.nytimes.com/2017/05/15/opinion/whiteflight.html. Accessed September 1, 2017

Gehl, Jan. 2010. Cities for People. Washington DC: Island Press.

- 2011. Three Types of Outdoor Activities, Life Between Buildings, and Outdoor Activities and the Quality of Outdoor Space. In The City Reader $5^{\text {th }}$ edition. Richard T. LeGates and Frederic Stout, eds. Pp. 530-539. Abingdon, UK: Routledge.

Holston, James. 2005. The Modernist City and the Death of the Street. In Theorizing the City: The New Urban Anthropology Reader. Edited by Setha M. Low. Pp. 245-276. New Brunswick: Rutgers University Press.

Hustwit, Gary, director. 2011. Design Trilogy: Urbanized. DVD series.

Jacobs, Jane. 1961. The Death and Life of Great American Cities. New York: Random House.

Palen, John J. 2012. The Urban World, $9^{\text {th }}$ edition. Boulder: Paradigm Publishers.

Sugrue, Thomas J. 1996. The Origins of the Urban Crisis: Race and Inequality in Postwar Detroit. Princeton: Princeton University Press.

Wilson, William Julius. 1996. When Work Disappears: The World of the New Urban Poor. New York: Vintage Books.

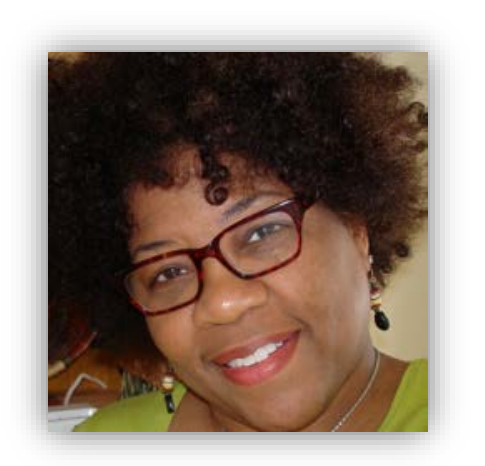

Calenthia Dowdy, PhD, is Associate Professor of Youth Ministry and Cultural Anthropology at Eastern University, St. Davids, PA. Her interests are in global urban youth cultures, and her doctoral research focused on youth in Cidade de Deus (City of God) favela in Rio de Janiero, Brazil.

Author email: cdowdy@eastern.edu. 